\title{
Banking Regulation and Determinants of Banks' Profits: Empirical Evidence from Turkey
}

\author{
Mahmut ERDOGAN", E. Ebru AKSOY**
}

\begin{abstract}
The crises that are frequently observed in the banking industries of emerging markets which affect banks' profits necessitate regulations and supervision of these markets. This paper investigates the determinants of Turkish banks' profits and the effects of the regulations implemented in this industry on profits. In this research, 468 firm year observations for 36 Turkish banks for the period 1995-2007 were used and analyzed with Prais-Winsten regression method. The empirical findings of the study show positive and statistically significant relations between capital, size, offbalance sheet transactions, liquidity and loans and performance and negative and statistically significant relations between quality of loans, concentration and performance.
\end{abstract}

Keywords: Profitability, Banking, Regulation, Prais-Winsten Regression, Turkey

JEL Code Classification: G21, G28, D2, K20

UDC: 336.71

DOI: https://doi.org/10.17015/ejbe.2016.017.07

\footnotetext{
Corresponding Author. Assistant Professor of Finance, Department of Finance and Banking, Kyrgyzstan-Turkey "Manas" University, Kyrgyzstan \& Department of Management, Gumushane University, Turkey. E-mail: mahmut.erdogan@manas.edu.kg

** Associate Professor of Finance, Department of Business Administration, Gazi University, Turkey. E-mail: eeakin@gazi.edu.tr 


\section{Introduction}

In the last twenty years in the global finance industry there have been significant developments in the areas of operations, regulations, technological innovations and globalization in the financial markets. The banking system, which is the most important element of the finance industry in Turkey, and its profits were significantly affected by these developments as they were by the crisis experienced in the country. In order to preserve the financial stability of the Turkish banking system, the Banking Regulation and Supervision Agency (BRSA) was established in 2000.

BRSA aims to ensure trust and stability in the Turkish banking system both in national and international financial markets, increase the competitive power of Turkish banks, ensure the efficiency of the loan system, ensure good regulations and effective supervision of financial markets and strengthen the industry through protecting investors. BRSA has an important role to play in keeping the Turkish banking sector strong and healthy. It is the guiding body in ensuring the application of corporate management and risk management principles in the Turkish banking sector, especially in increasing capital adequacy and profitability. Although there are many studies regarding the determinants of banking profits, the relations between banking regulations and bank profits have not been investigated. It is intended that this study will shed light on the literature related to this topic.

In recent years banking regulations and determinants of bank profits have been a subject of interest in the empirical literature. On this topic, the studies of Angkinand (2009), Pasiouras et al. (2009); Goddard et al(2004b); Pasiouras and Kosmidou, (2007); Goddard et al. (2011); Chen and Liao (2011) who made an international comparison, Athanasoglou et al. (2008) for Greece, Rasiah (2010) for Malaysia, García-Herrero et al. (2009) for China, Sayilgan and Yildirim (2009) for Turkey attract attention.

The aim of this study is to define the internal factors that affect the profitability of the banks that were operating in Turkey between 1995-2007 and the effects of the establishment of BRSA on bank profitability after 2002. The empirical findings of the study determined positive and statistically significant relations between capital, size, off-balance sheet transactions, liquidity and loans and performance and negative relations between quality of loans, concentration and performance.

The remainder of this study is structured as follows: Section 2 reviews the empirical literature on the determinants of bank profitability. Section 3 describes the data and methodology. Section 4 shows Turkish banks' profitability determinants for the 1995-2007 periods. Section 5 concludes the findings.

\section{Literature}

Recently, an increase has been observed in the number of empirical studies on banking profitability and its determinants. These studies have been developed 
based on the "collusion" and "efficiency" theories. The collusion hypothesis claims that a small number of banks can make an agreement to increase interest rates and fee amounts for loans and decrease the interest given for deposits. Increasing the number of banks in the market makes collusion more difficult. On the other hand, the efficiency hypothesis states that an increase in a bank's size will increase efficiency as well. Yet it is not clear whether the high profits of banks are because of collusion or efficiency.

The scarcity of studies in the literature about banking market regulations and the effects of these regulations on the determinants of profitability is remarkable. Angkinand $(2009,241)$ who reviewed whether strong banking regulations are effective in decreasing the costs of banking crises or not concluded that in countries where deposit insurance is high, capital adequacy is strictly implemented and banking activities are less restricted, banks' profits are less affected by the crisis. However, this study claimed that the results obtained regarding effects of banking regulations are dependent on whether the banking crisis is systematic or not and whether they issued excessive loans or not prior to the crisis. Moreover, from the perspective of bank supervision, this study failed to establish significant relations regarding the negative effects of the crisis. Pasiouras et al. (2009), who offered international empirical evidence regarding the effects of banking regulations on bank costs and profit, claimed that cost effective banks do not have sufficiently effective profits, that the effectiveness of both costs and profits are positively affected by high level official supervision power, disclosure necessities and incentives increasing market discipline. Additionally, while regulations increase official supervisory power, market discipline mechanisms increase bank effectiveness. Furthermore, they pointed out that the regulations have to consider the interaction between competition, effectiveness and financial stability.

According to Allen and Gale (2004), although they may be large and visible the costs of a financial crisis rarely emerge, even though the effects of inefficiency are continuous. Fernández et al. (2013) stated that in the crisis periods there is a different interaction between limitations towards non-traditional banking activities and having deposit insurance and bank market power, and in normal periods, there is a positive interaction between capital limitations only. On the other hand, Naceur and Omran (2011) reported that banking regulations are effective on bank performance and the improvements in regulations decrease costs without affecting performance, while corruption increases costs and net interest rates. Barth et al. (2004) stated that regulations and supervision applications that support correct information disclosure and limit moral risks that arise due to well-planned deposit insurance plans positively increase banks' development, performance and stability.

Regulations made in the banking sector are among the factors that are effective on bank performance. The studies in the literature that investigate the factors that are effective on bank performance can be classified as those that consider bankspecific, industry-specific and macroeconomic variables [Goddard et al. 2004a; 
Athanasoglou et al 2008; Pasiouras and Kosmidou, 2007; Pasiouras et al. 2009; Sufian 2009; Sayilgan and Yildirim 2009; García-Herrero et al. 2009; Rasiah 2010] and those that focus on only one country or those that cross-countries [Goddard et al 2004b; Pasiouras and Kosmidou, 2007; Goddard et al 2011; Chen and Liao 2011].

Goddard (2004a), which is one of the fundamental studies conducted to identify banking profit determinants, analyzed with the Generalized Method of Moments and bank profitability determinants for six countries in Europe for the period between 1992-1998. This study identified efficiency as a more important performance determinant than size. With regards to relations to profitability and off-balance sheet transactions, a positive relation was found for England, and neutral or negative relations were found for the other countries. The study found that banks that quickly diversify off-balance sheet transactions struggled to sustain their profitability. Athanasoglou et al. (2008), in the study that reviewed the bank industry and macro determinants of banking profitability used the period between 1985-2001 for Greek banks. A positive relation between bank profitability and capital and employee productivity and a negative relation between operating expenditure was found.

Pasiouras and Kosmidou (2007), which dealt with profit determinants of European banks from the perspective of bank-specific and macroeconomic variables, revealed that bank profits are affected by factors specific to the bank as well as by financial market and macroeconomic conditions. Moreover, the negative relation between size and profitability was pointed out, and instead of consolidation policies that will increase bank size, increasing cost control efficiency was suggested.

García-Herrero et al. (2009), who researched the low profitability in Chinese banks, found that banks which can increase market value, deposit rate and X-efficiency can also increase their profits. Furthermore, a less intensified banking system was claimed to increase bank profits. Goddard et al. (2011), who analyzed the effects of intense competition on bank profits by comparing countries found a positive relation between bank profitability and industry concentration level, and a negative relation between competition conditions. Furthermore, within the framework of regulations and supervision, they pointed out that competition is effective in converging the profits to the equilibrium point in the long run. Narwal and Pathneja (2015) analyzed the determinants of Indian's banks profitability during 2003-2014. Fixed effects panel data results showed that both diversification and spread were positively related too banks' profitability. However, they also found that larger banks are more profitable than smaller banks. Rahman, Zheng, and Ashraf (2015) investigated the impact of bank size on bank regulatory capital ratios and risk taking behaviors of Bangladeshi commercial banks by using dynamic panel data method. They found that banks with higher levels of regulatory capital are less risky while large banks hold lower amount of capital and also take higher level of risk. 


\section{Data and Methodology}

In this section, the data and the empirical model for profitability determinants in Turkish banking sector are defined. The data used in the study were collected from the Banks Association of Turkey database. The profitability was measured by three alternative variables; the first was the return on assets (ROA), second the return on equity (ROE), and third the earning per person (EPP). Although basically ROA can be negatively affected by off-balance sheet transactions, it shows the bank management's ability to obtain profits from the assets (Athanasoglou et al. 2008, 126). ROE shows the profit the shareholders obtain over the equity. Earning per person was used as another bank performance indicator. While there had been a very steep decline in ROA in the pre-crisis period before 2001, Figure 1 shows the rapid increase in ROA following regulations on the banking system after 2001.

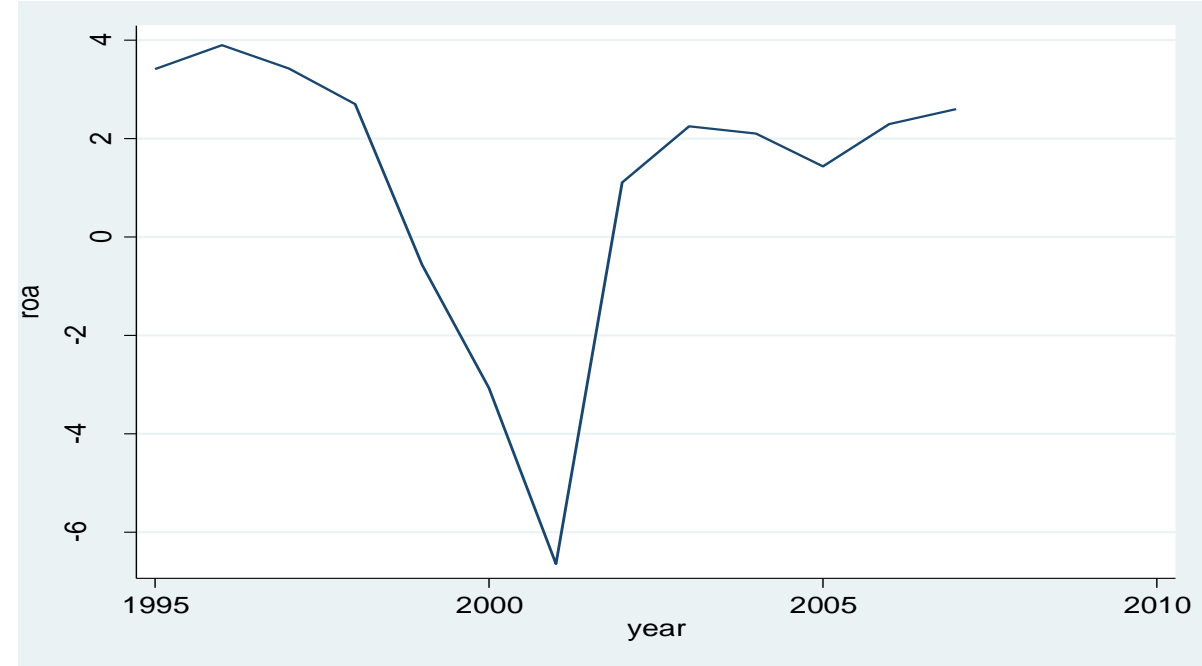

Figure 1. ROA trends of Turkish banking system

Source: Turkish Banking Association, Our Banks, 2012

In this study, the following variables were used: EA for equity to assets ratio that represents bank capital, NLA for ratio of non-performing loans to total loans representing credit risk, SIZE representing bank size, CONC for concentration that shows the market structure, OBS in which the banks' derivative instruments, letters of credit and non-traditional and off-balance sheet transactions are calculated as off-balance sheet assets divided by sum of off-balance sheet assets and total assets, LIQ which is calculated as the liquid assets to total assets to represent the liquidity risk, and CTS which is calculated as credits to total assets to represent the credit risk. The variables used in the study, their explanations, notations and expectations about the variables are summarized in Table 1. 
Mahmut ERDOGAN \& E. Ebru AKSOY

Table 1. The explanations and expected signs of the variables

\begin{tabular}{lllc}
\hline Variable & Measure & Notation & $\begin{array}{c}\text { Expected } \\
\text { Sign }\end{array}$ \\
\hline Profitability & net profits/assets or net profits/equity or net & ROA, ROE or & \\
& profits/number of person & EPP & + \\
Capital & equity/assets & EA & - \\
Credit Risk & non-performing loan/total loans & NLA & + \\
Size & natural logarithm of total assets in liras & SIZE & $?$ \\
Concentration & $\begin{array}{l}\text { assets of five largest banks as a share of assets } \\
\text { of all commercial banks }\end{array}$ & & + \\
off-balance sheet & the nominal value of OBS/total assets + the & OBS & + \\
Liquidity Risk & nominal value of OBS value & LIQ & + \\
Assets & liquid assets / total assets & CTS & + \\
Compositions & total credits/ total assets & & \\
\hline
\end{tabular}

In this study, the determinants of profitability for Turkish banks for the period between 1995-2007 were analyzed with the balanced panel data method. A sample consisting of 468 firm years observations for 36 banks in the Turkish banking sector was used. In order to identify bank profitability determinants, we created the models in Equations 1, 2 and 3 following Goddard et al. (2004: 361), Athanasoglou et al (2008: 125), Pasiouras and Kosmidou (2007: 229) and Ben Naceur and Omran (2011: 7).

$R O A_{i t}=\alpha_{t}+\beta_{1} E A_{i t}+\beta_{2} N L A_{i t}+\beta_{3} S I Z E_{i t}+\beta_{4} C O N C_{i t}+\beta_{5} O B S_{i t}+\beta_{6} L I Q_{i t}+$ $\beta_{7} C T S_{i t}+\varepsilon_{i t}$

$R O E_{i t}=\alpha_{t}+\beta_{1} E A_{i t}+\beta_{2} N L A_{i t}+\beta_{3} S_{I Z E_{i t}}+\beta_{4} \operatorname{CONC}_{i t}+\beta_{5} O B S_{i t}+\beta_{6} L I Q_{i t}+$ $\beta_{7}$ CTS $_{i t}+\varepsilon_{i t}$

$E P P_{i t}=\alpha_{t}+\beta_{1} E A_{i t}+\beta_{2} N L A_{i t}+\beta_{3} \operatorname{SIZE}_{i t}+\beta_{4} \operatorname{CONC}_{i t}+\beta_{5} O B S_{i t}+\beta_{6} L I Q_{i t}+$ $\beta_{7} \operatorname{CTS}_{i t}+\varepsilon_{i t}$

$\varepsilon_{i t}=v_{i}+u_{i t}$

where $R O A_{i t}$ refers to the return on assets and is the observation of a bank in a particular year, $t ; X_{i t}$ shows the internal determinants of a bank and $\varepsilon_{i t}$ is a normally distributed variable disturbance term with $v_{i}$ the unobserved bankspecific effect and $u_{i t}$ the idiosyncratic error. First, static panel data methods were used in this study, but since heteroscedasticity, cross sectional dependency and autocorrelation were identified, Prais-Winsten regression analysis was conducted (see Appendix). Panel corrected standard error estimators suggest that the disturbances are assumed to be heteroscedastic and contemporaneously correlated across banks and also autocorrelated within banks. The model can be written bank by bank as 
Banking Regulation and Determinants of Banks' Profits: Empirical Evidence from Turkey

$\left[\begin{array}{c}y_{1} \\ y_{2} \\ \vdots \\ y_{k}\end{array}\right]=\left[\begin{array}{c}x_{1} \\ x_{2} \\ \vdots \\ x_{k}\end{array}\right] \beta+\left[\begin{array}{c}\varepsilon_{1} \\ \varepsilon_{2} \\ \vdots \\ \varepsilon_{k}\end{array}\right]$, or $y_{i t}=x_{i t} \beta+\varepsilon_{i t}$

where $y_{i t}$ and $x_{i t}$ are $T \times 1$ vectors of observations on the dependent and explanatory variables for the $i^{\text {th }}$ group, $i=1,2, \ldots ., k ; \beta$ is a $2 \times 1$ vector of coefficients and $\varepsilon_{i}$ is a $T \times 1$ vector of error terms and also $\varepsilon \sim N\left(0, \Omega_{N T}\right)$. Beck and Katz (1995) allow $\Omega_{N T}$ to consist of heteroscedasticity, first-order serial correlation and cross-sectional correlation as well. Particularly,

$\Omega_{N T}=\Sigma \otimes \Pi$,

Where, $\Sigma=\left[\begin{array}{cccc}\sigma_{\varepsilon, 11} & \sigma_{\varepsilon, 12} & \ldots & \sigma_{\varepsilon, 1 k} \\ \sigma_{\varepsilon, 21} & \sigma_{\varepsilon, 22} & \ldots & \sigma_{\varepsilon, 2 k} \\ \cdot & \cdot & & \cdot \\ \sigma_{\varepsilon, k 1} & \sigma_{\varepsilon, k 2} & . . & \sigma_{\varepsilon, k k}\end{array}\right]$, and

$\Pi=\left[\begin{array}{cccc}1 & \rho & \rho^{2} & \rho^{T-1} \\ \rho & 1 & \rho & \rho^{T-2} \\ \rho^{2} & \rho & 1 & \rho^{T-3} \\ \rho^{T-1} & \rho^{T-2} & \rho^{T-3} & 1\end{array}\right]$, and $\varepsilon_{i t}=\rho \varepsilon_{i t-1}+u_{i t}$

Beck and Katz (1995) hold by selecting several combinations of $k$ and $T$ and embodying the values of $\rho$ and $\sigma_{\varepsilon, i j}, i, j=1,2, \ldots \ldots, k$, in $\Omega_{k T}$.

Beck and Katz (1995) calculate the panel corrected standard errors estimators for $\hat{\beta}$ and $\operatorname{Var}(\widehat{\beta})$ using the formulae in Equation (9).

$\hat{\beta}_{P C S E}=\left(\tilde{X}^{\prime} \tilde{X}\right)^{-1} \tilde{X} \tilde{y}, \operatorname{Var}\left(\hat{\beta}_{P C S E}\right)=\left(\tilde{X}^{\prime} \tilde{X}\right)^{-1}\left(\tilde{X}^{\prime} \sum \tilde{X}\right)\left(\tilde{X}^{\prime} \tilde{X}\right)^{-1}$,

where $\tilde{X}$ and $\tilde{y}$ are the Prais-transformed observations of the independent and dependent variables, and $\Sigma$ is defined in Equation (6).

This analysis makes predictions under the panel corrected standard errors Bankspecific $A R(1)$ assumptions. Thus, in predicted models, the variance for each bank data and the covariance for each bank pair were assumed to be unique. The summary statistics for the variables are presented in Table 2.

As can be seen in Table 2, average ROA is 3.13, ROE is 28.37 and EPPaverage is 9.9. Correlation values for variables are presented in Table 3 . Table 3 provides information regarding the degree of relation between the explanatory variables used in the panel data analysis. The correlation matrix shows that there is no 
relation between the variables that may cause multicollinearity. Kennedy (2008) states that when there is a correlation over 0.80 , a multicollinearity issue will arise, and all the values in Table 3 are below this value.

Table 2. Descriptive statistics of variables

\begin{tabular}{lccccc}
\hline Variable & Obs & Mean & Std. Dev. & Min & Max \\
\hline ROA & 468 & 3.13 & 7.83 & -63.24 & 56.9 \\
ROE & 468 & 28.37 & 104.34 & -1727.41 & 682.94 \\
EPP & 468 & 9.9 & 2.13 & 0 & 14.16 \\
EA & 468 & 21.14 & 19.72 & -2.68 & 93.11 \\
NLA & 468 & 5.09 & 12.45 & 0 & 150 \\
SIZE & 468 & 19.95 & 2.59 & 11.84 & 25.12 \\
CONC & 468 & 66.67 & 9.88 & 51.46 & 78.71 \\
OBS & 468 & 0.54 & 0.24 & 0 & 1 \\
LIQ & 468 & 46.46 & 22.25 & 1.83 & 98.72 \\
CTS & 468 & 32.96 & 22 & 0 & 92.23 \\
\hline
\end{tabular}

Table 3. Correlation coefficients of variables

\begin{tabular}{llllllll}
\hline & EA & NLA & \multicolumn{1}{c}{ SIZE } & CONC & OBS & LIQ & CTS \\
\hline EA & 1 & & & & & & \\
NLA & 0.075 & 1 & & & & & \\
SIZE & -0.290 & -0.136 & 1 & & & & \\
CONC & 0.183 & -0.094 & 0.514 & 1 & & & \\
OBS & -0.060 & -0.112 & 0.149 & 0.119 & 1 & & \\
LIQ & 0.113 & 0.103 & -0.353 & -0.005 & 0.123 & 1 & \\
CTS & -0.115 & -0.181 & 0.334 & 0.020 & -0.003 & -0.712 & 1 \\
\hline
\end{tabular}

\section{Empirical Findings}

Table 4 shows the empirical findings of the predicted model using ROA as the profitability variable. The model located in the first column of the table covers the whole sample, while the model for the 1995-2000 pre-BRSA regulations period is presented in the second column and after the banking crisis time model for the 2001-2007 post-BRSA regulations period is presented in the third column. The majority of the variables in the first column, except for OBS, are statistically significant at the $1 \%$ level.

The coefficient for the capital variable (EA) is positive and statistically significant. A bank with a strong capital structure can more effectively utilize potential business opportunities and increase profitability as it has more flexibility to eliminate unpredictable deficiencies (Athanasoglou et al;2008, 132). Sufian (2009) stated that a strong capital structure for banks in emerging markets is important as it reassures deposit holders and provides additional support to banks in an unstable macroeconomic environment. 
Banking Regulation and Determinants of Banks' Profits: Empirical Evidence from Turkey

Table 4. Determinants of bank profitability with respect to return onassets

\begin{tabular}{|c|c|c|c|c|c|c|}
\hline \multirow{2}{*}{$\frac{R O A}{E A}$} & \multicolumn{2}{|c|}{ 1995-2007 full sample } & \multicolumn{2}{|c|}{ 1995-2000 pre-BRSA } & \multicolumn{2}{|c|}{ 2002-2007 post-BRSA } \\
\hline & $0.066 * *$ & $(0.028)$ & $0.155^{* * *}$ & $(0.044)$ & 0.056 & $(0.034)$ \\
\hline NLA & $-0.145 * * *$ & $(0.056)$ & $-0.074 * * *$ & $(0.025)$ & $-0.375 * * *$ & (0.107) \\
\hline SIZE & $0.743^{* * *}$ & (0.209) & $0.872^{* * *}$ & ( 0.178) & $1.017 * * *$ & $(0.334)$ \\
\hline CONC & $-0.433 * * *$ & (0.057) & $-0.692 * * *$ & (0.109) & $-0.561 * *$ & $(0.237)$ \\
\hline OBS & 0.161 & $(1.564)$ & 1.24 & ( 1.454$)$ & 0.164 & (2.319) \\
\hline LIQ & $0.102 * * *$ & $(0.026)$ & $0.106 * * *$ & ( 0.031$)$ & $0.0862 * *$ & $(0.041)$ \\
\hline CTS & $0.0832 * * *$ & $(0.026)$ & 0.0472 & $(0.031)$ & $0.069 *$ & $(0.036)$ \\
\hline Constant & $8.516^{* *}$ & $(4.233)$ & $18.76^{* * *}$ & (5.588) & 15.3 & $(15.29)$ \\
\hline Observations & \multicolumn{2}{|c|}{468} & \multicolumn{2}{|c|}{216} & \multicolumn{2}{|c|}{216} \\
\hline R-squared & \multicolumn{2}{|c|}{0.306} & \multicolumn{2}{|c|}{0.43} & \multicolumn{2}{|c|}{0.415} \\
\hline Number of id & \multirow{2}{*}{\multicolumn{2}{|c|}{$\begin{array}{c}36 \\
8379(7)(0) 1\end{array}$}} & \multicolumn{2}{|c|}{$\begin{array}{c}36 \\
14476(7)(000)\end{array}$} & \multirow{2}{*}{\multicolumn{2}{|c|}{$\begin{array}{c}36 \\
46.6(7)(0.00)\end{array}$}} \\
\hline Wald chi2 & & & $144.76(7$ & ( 0.00$)$ & & \\
\hline
\end{tabular}

Standard errors in parentheses ${ }^{* * *} p<0.01,{ }^{* *} p<0.05,{ }^{*} p<0.1$

In accordance with expectations, a negative relation between credit risk (NLA) and profitability was found. According to this, as the non-performing loans increase, the bank's profitability decreases. As the banks' non-performing loans represent their non-collectible receivables, they may cause losses and ultimately may decrease profits. The increase in the amount of non-performing loans puts the banks in a tight spot; the banks also have to decrease their profit margins to eliminate this situation.

It is a fact that the relation between the profitability and size variables for Turkish banks is positive and it supports the outcomes of Kosmidou (2008) and Sufian (2009). There are two possible reasons why size positively affects bank performance. The first is that since large banks have market power they have lower risks and can pay more interest on deposits. Second is that earnings that may increase with scale through decreasing costs and increasing operation leverage by using the efficiency of high business volumes or a specialized workforce. When it is observed from the Turkish banking sector's perspective, possible cost advantages through product and risk diversification may explain the relation between size and profitability.

Empirical findings show that concentration (CONC) negatively affects bank profitability and it is statistically quite strong. As concentration increases in the Turkish banking sector, the five largest banks in the market may benefit from economies of scale. On the other hand, the small banks' inability to compete with the large banks decreases their profits. Liquidity (LIQ) variable's coefficient is positive and is statistically significant at the $1 \%$ level. This evidence is consistent with the outcome of Pasiouras and Kosmidou (2007). Kaya (2002) claims that banks owning low return assets in the Turkish banking sector open interest margins 
explains the positive relationship between liquidity and profitability variables by banks reflecting the spread in interest margins on bank profitability.

The positive and statistically strong relation between credits (CTS) and bank profits variables shows that banks can transform the expansion in their credit portfolio to high interest margins and profits. However, expansionist credit policies increase bank performance. Also, there is 71.74

(0.00)no strong statistical finding between off-balance sheet transactions (OBS) and bank profitability.

The second and third models in Table 4 show the empirical findings in the banking sector before and after the regulations. While the capital variable was found to be positive and statistically significant at the $1 \%$ level before the regulations, no significant empirical evidence was obtained for the post-regulation period.

Furthermore, credit risk and size were identified as very important determinants of profitability. The regulation caused credit risk to further decrease profitability in the Turkish banking sector. With the effects of the regulation, the coefficient of the NLA variable increased from $7 \%$ to $38 \%$. This situation shows that credit risk in the Turkish banking sector became important at a vital level. Similarly, size variables became more important following the regulations. This situation provides evidence that supports the efficiency hypothesis as well. After the regulation, the effect of concentration on profitability was observed to decrease. A decrease in the effect of liquid assets on profitability was determined. The main reasons for this were the crises and uncertainty situation in the Turkish financial markets causing banks to hold more liquid assets. Since the cost associated with the risk of not having liquidity in crisis periods is higher than resource costs, liquidity increases in these times are expected to increase profits. However, in regular operation periods the resource costs for idle funds borne in connection with the increase in liquidity are expected to decrease profits. The increases in the importance of loans in determining bank profits are expected during expansionist credit policies implemented in the post-regulation period.

In the first model in Table 5 where ROE was used as a profitability indicator, all variables except size are statistically significant and their signs are found to be parallel with the theoretical expectations. Differently from the models in Table 4, the OBS variable was found to be positive and statistically significant for all and pre-regulation period. While the OBS variable is not statistically significant in the post-regulation period, it has a negative coefficient in a manner that supports the findings of Sayilgan and Yildirim (2009). Moreover, Aktan, Chan and Evrim-Mandaci (2013) found that OBS activities are negatively related with return on equity of Turkish commercial banks for the 2001-2008 periods. They suggested that when OBS activities significantly decrease the risk exposure of the commercial banks, shareholders will expect returns to decline. 
Banking Regulation and Determinants of Banks' Profits: Empirical Evidence from Turkey

Table 5. Determinants of bank profitability with respect to return on equity

\begin{tabular}{|c|c|c|c|c|c|c|}
\hline ROE & \multicolumn{2}{|c|}{ 1995-2007 full sample } & \multicolumn{2}{|c|}{$1995-2000$ pre-BRSA } & \multicolumn{2}{|c|}{ 2002-2007 post-BRSA } \\
\hline EA & $0.438 * *$ & $(0.216)$ & -0.181 & $(0.294)$ & 0.163 & $(0.126)$ \\
\hline NLA & $-0.568 * * *$ & $(0.218)$ & $-0.859 * *$ & $(0.376)$ & $-0.562 * * *$ & $(0.158)$ \\
\hline SIZE & 2.908 & ( 2.127) & $5.098 * *$ & (2.289) & $5.123 * * *$ & $(1.463)$ \\
\hline CONC & $-4.102 * * *$ & $(0.800)$ & $-3.748 * *$ & (1.728) & $-1.759 * *$ & $(0.895)$ \\
\hline OBS & $67.33 * * *$ & (16.7) & $61.06 * * *$ & (21.01) & -0.233 & ( 6.520) \\
\hline LIQ & $1.000 * * *$ & $(0.312)$ & $0.727^{* * *}$ & (0.278) & 0.17 & (0.164) \\
\hline CTS & $1.027 * *$ & $(0.406)$ & 0.247 & (0.239) & 0.0938 & (0.167) \\
\hline Constant & $115.9 *$ & (59.59) & 114.2 & (95.63) & 18.75 & (61.73) \\
\hline Observations & & 468 & & 216 & & 216 \\
\hline R-squared & & 0.124 & & 0.375 & & 0.227 \\
\hline Number of id & & 36 & & 36 & & 36 \\
\hline Wald chi2 & 52.9 & $1(7)(0.00)$ & 49.4 & $43(7)(0.00)$ & & $.99(7)(0.00)$ \\
\hline
\end{tabular}

In Table 6, models using earnings per person (EPP) as the profitability variable are presented. For the entire period, size, concentration and loan variables were found to be statistically important, only size and concentration are significant in the preregulation period. In the post-regulation period, concentration, OBS and liquidity risk variables are meaningful. As opposed to the findings in Table 4 and 5, Table 6 reports a positive relation between concentration and profitability.

Table 6. Determinants of bank profitability with respect to earnings per person

\begin{tabular}{|c|c|c|c|}
\hline EPP & 1995-2007 full & 1995-2000 pre-BRSA & 2002-2007 post-BRSA \\
\hline EA & $(0.006)$ & $(0.012)$ & $(0.005)$ \\
\hline NLA & $-0.005 \quad(0.005)$ & $(0.008)$ & (0.007) \\
\hline SIZE & $0.154 * * * \quad(0.051)$ & $0.257 * * *(0.087)$ & ( 0.048$)$ \\
\hline CONC & $0.100 * * *(0.019)$ & $0.121 * * \quad(0.051)$ & $0.143 * * \quad(0.070)$ \\
\hline OBS & $(0.433)$ & $(0.709)$ & $1.038 * * \quad(0.527)$ \\
\hline LIQ & $(0.006)$ & $0.0002 \quad(0.014)$ & $-0.009 * \quad(0.006)$ \\
\hline CTS & $-0.019 * * *(0.006)$ & ( 0.013) & ( 0.007$)$ \\
\hline Constant & (1.473) & (3.509) & ( 5.405$)$ \\
\hline Observations & 468 & 216 & 216 \\
\hline R-squared & 0.752 & 0.589 & 0.934 \\
\hline Number of id & 36 & 36 & 36 \\
\hline Wald chi2 & $55.47(7)(0.00)$ & $31.75(7)(0.00)$ & $9.46(7)(0.22)$ \\
\hline
\end{tabular}

\section{Conclusion}

The Turkish banking sector that has a predominant share in the financial system has been significantly affected by both international developments and national financial crises in the last twenty years. In order to decrease the effects of the banking crises and to ensure stability in the industry, various institutional and legal 
regulations were implemented. The most important one of these regulations was the establishment of BRSA as the regulatory body.

The aim of this paper was the identification of the profitability determinants in the Turkish banking industry and the effect of the regulatory body on profitability. With this purpose in mind, the data for the 1995-2007 periods in the Turkish banking sector were used and the sample was separated into two sub periods representing the $1995-2000$ pre-regulatory period and the 2002-2007 post-regulatory periods.

The empirical findings of the study show a positive statistically significant relationship between the capital variable and bank performance. This situation signals that banks with larger capital in the Turkish banking sector will increase their profitability. In line with the increase of non-performing loans among total loans, it was observed that profitability is inclined to decrease. It was found that especially in the post-regulation period, loan quality became more important in determining credits. Size variable was also found to be positive and statistically quite important. When analyzed from a period basis, it was observed that the importance of size increased in the post-regulation period. A positive, statistically significant relation was identified between the OBS variable and performance. This situation shows that the Turkish banks create a profit increasing effect through derivative instruments, letters of credit and non-traditional banking transactions. Liquid assets and loans variables were found to positively affect profitability.

As a result, it can be said that authority has a positive effect on the profitability of the Turkish banking industry. In following studies, in addition to bank-specific factors, including industrial and macroeconomic factors will provide a wider perspective.

\section{References}

Aktan, B., Chan, S.G, Žiković, S., \& Evrim-Mandaci, P. (2013). Off-balance sheet activities impact on commercial banks performance: An emerging market perspective. $\begin{array}{llll}\text { Ekonomskaistraživanja - Economic 117-132. } & \text { 26(3), Research, }\end{array}$ http://dx.doi.org/10.1080/1331677X.2013.11517625.

Allen, F., \& Gale, D. (2004). Competition and financial stability. Journal of Money, Credit and Banking, 36, 453-480.

Angkinand, A.P. (2009). Banking regulation and the output cost of banking crises. International Financial Markets, Institutions and Money, 19, 240-257. http://dx.doi.org/10.1016/j.intfin.2007.12.001.

Athanasoglou, P.P., Brissimis, S.N., \& Delis, M.D. (2008). Bank specific, industry specific and macroeconomic determinants of bank profitability. Journal of International Financial Markets, Institutions and Money, 18(2), 121-136. http://dx.doi.org/10.1016/j.intfin.2006.07.001.

Barth, J.R., Caprio, G. Jr., \& Levine, R. (2004). Bank regulation and supervision: what works best? Journal of Financial Intermediation, 13, 205-248. http://dx.doi.org/10.1016/j.jfi.2003.06.002. 
Beck, N., \& Katz, J.N. (1995). What To Do (and Not To Do) With Time Series Cross-Section Data. American Political Science Review, Vol. 89, No.3.

Ben Naceur S., \& Omran, M. (2011). The effects of bank regulations, competition, and financial reforms on banks' performance. Emerging Markets Review, 12, 1-20. http://dx.doi.org/10.1016/j.ememar.2010.08.002.

Chen, S.H., \& Liao, C.C. (2011). Are foreign banks more profitable than domestic banks? Home- and host-country effects of banking market structure, governance, and supervision. $\begin{array}{llll}\text { Journal of Banking } \text { and } & \text { 819-839. }\end{array}$ http://dx.doi.org/10.1016/j.jbankfin.2010.11.006.

Fernández, A.I., González F., \& Suárez N. (2013). How do bank competition, regulation, and institutions shape the real effect of banking crises? International evidence. Journal of International Money and Finance, 33, 19-40. http://dx.doi.org/10.1016/j.jimonfin.2012.10.002.

García-Herrero A., Gavilá, S., \& Santabárbara, D. (2009). What explains the low profitability of Chinese banks? Journal of Banking and Finance, 33, 2080-2092. http://dx.doi.org/10.1016/j.jimonfin.2012.10.002.

Goddard, J., Molyneux, P., \& Wilson, J. (2004). Dynamic of growth and profitability in banking". Journal of Money, Credit and Banking, 36(6), 1069-1090.

Goddard, J., Molyneux, P., \& Wilson, J.O.S., (2004). The profitability of European banks: a cross-sectional and dynamic panel analysis. Manchester School, 72 (3), 363-381. http://dx.doi.org/10.1111/j.1467-9957.2004.00397.x.

Goddard J., Liu, H., Molyneux, P., \& Wilson, J.O.S. (2011). The persistence of bank profit. Journal of Banking and Finance, 35, 2881-2890. http://dx.doi.org/10.1016/j.jbankfin.2011.03.015.

Kaya, T.Y. (2002). Determinants of Profitability in Turkish Banking Sector, (in Turkish) Turkish Banking Regulation and Supervision Agency, No: 2002/1.

Kennedy, P., (2008). A guide to econometrics, Malden: Blackwell Publishing.

Kosmidou, K. (2008). The determinants of banks' profits in Greece during the period of EU financial integration. Managerial Finance, 34(3), 146-159. http://dx.doi.org/ 10.1108/03074350810848036.

Narwal, K.P., \& Pathneja S. (2015). Determinants of Productivity and Profitability of Indian Banking Sector: A Comparative Study, Eurasian Journal of Business and Economics, 8(16), 3558. http://dx.doi.org/10.17015/ejbe.2015.016.03

Pasiouras F., Tanna, S., \& Zopounidis, C. (2009). The impact of banking regulations on banks' cost and profit efficiency: Cross-country evidence. International Review of Financial Analysis, 18, 294-302. http://dx.doi.org/10.1016/j.irfa.2009.07.003.

Pasiouras, F., Kosmidou, K. (2007). Factors influencing the profitability of domestic and foreign commercial banks in the European Union. Research in International Business and Finance, 21(2), 222-237. http://dx.doi.org/10.1016/j.ribaf.2006.03.007.

Rahman, M.M., Zheng, C., \& Ashraf, B.N. (2015). Bank Size, Risk-taking and Capital Regulation in Bangladesh, Eurasian Journal of Business and Economics, 8 (15), 95-114. http://dx.doi.org/10.17015/ejbe.2015.015.05

Rasiah, D. (2010). Theoretical Framework of Profitability as Applied to Commercial Banks in Malaysia. European Journal of Economics, Finance and Administrative Sciences, 19, 74-97. 
Mahmut ERDOGAN \& E. Ebru AKSOY

Sayilgan, G., \& Yildirim O. (2009). Determinants of Profitability in Turkish Banking Sector: 2002-2007. International Research Journal of Finance and Economics, 28, 207-214.

Sufian, F. (2009). Determinants of Bank Profitability in a Developing Economy: Empirical Evidence from the China Banking Sector. Journal of Asia-Pacific Business, 10, 281-307. http://dx.doi.org/10.1080/10599230903340205.

\section{Appendices}

Table A.1. Determinants of bank profitability over 1995-2007 (full sample)

\begin{tabular}{|c|c|c|c|c|c|c|}
\hline & Fixed & Random & Fixed & Random & Fixed & Random \\
\hline & ROA & ROA & ROE & ROE & EPP & EPP \\
\hline \multirow[t]{2}{*}{ EA } & $0.080 * * *$ & $0.090 * * *$ & 0.733* & 0.394 & $0.018 * * *$ & $0.015^{* * *}$ \\
\hline & $(-0.024)$ & $(-0.021)$ & $(-0.396)$ & $(-0.27)$ & $(-0.006)$ & $(-0.005)$ \\
\hline \multirow[t]{2}{*}{ NLA } & $-0.135 * * *$ & $-0.167 * * *$ & -0.359 & $-0.854^{* *}$ & -0.002 & -0.007 \\
\hline & $(-0.028)$ & $(-0.026)$ & $(-0.471)$ & $(-0.38)$ & $(-0.007)$ & $(-0.007)$ \\
\hline \multirow[t]{2}{*}{ SIZE } & 0.009 & $0.475 * *$ & 2.153 & 3.24 & $0.435 * * *$ & $0.224 * * *$ \\
\hline & $(-0.366)$ & $(-0.235)$ & $(-6.164)$ & $(-2.634)$ & $(-0.093)$ & $(-0.061)$ \\
\hline \multirow[t]{2}{*}{ CONC } & $-0.314 * * *$ & $-0.388 * * *$ & $-3.831 * * *$ & $-3.853 * * *$ & $0.056 * * *$ & $0.087 * * *$ \\
\hline & $(-0.063)$ & $(-0.046)$ & $(-1.057)$ & $(-0.612)$ & $(-0.016)$ & $(-0.012)$ \\
\hline \multirow[t]{2}{*}{$\mathrm{OBC}$} & $-4.283^{* *}$ & -0.78 & 44.56 & $48.41 * *$ & -0.183 & -0.148 \\
\hline & $(-1.69)$ & $(-1.492)$ & $(-28.49)$ & $(-19.96)$ & $(-0.431)$ & $(-0.384)$ \\
\hline \multirow[t]{2}{*}{ LIQ } & $0.105^{* * *}$ & $0.092 * * *$ & $0.788 * *$ & $0.832 * * *$ & -0.004 & 2.89E-05 \\
\hline & $(-0.023)$ & $(-0.021)$ & $(-0.387)$ & $(-0.308)$ & $(-0.006)$ & $(-0.006)$ \\
\hline \multirow[t]{2}{*}{ CTS } & $0.102^{* * *}$ & $0.074 * * *$ & $0.987^{* *}$ & $0.683 * *$ & $-0.026 * * *$ & $-0.017^{* * *}$ \\
\hline & $(-0.024)$ & $(-0.022)$ & $(-0.405)$ & $(-0.306)$ & $(-0.006)$ & $(-0.006)$ \\
\hline \multirow[t]{2}{*}{ Constant } & $16.91 * * *$ & $12.14^{* * *}$ & $134.1^{*}$ & $129.5^{* * *}$ & -1.722 & -0.032 \\
\hline & $(-4.384)$ & $(-3.521)$ & $(-73.91)$ & $(-48.63)$ & $(-1.119)$ & $(-0.907)$ \\
\hline R-squared & 0.296 & 0.285 & 0.129 & 0.122 & 0.439 & 0.429 \\
\hline \multirow[t]{2}{*}{ F stat } & 25.54 & & 8.95 & & 47.6 & \\
\hline & $(0.000)$ & & $(0.000)$ & & $(0.000)$ & \\
\hline \multirow[t]{2}{*}{ Wald } & & 183.72 & & 69.39 & & 310.52 \\
\hline & & $(0.000)$ & & $(0.000)$ & & $(0.000)$ \\
\hline Observations & 468 & 468 & 468 & 468 & 468 & 468 \\
\hline Number of id & 36 & 36 & 36 & 36 & 36 & 36 \\
\hline \multirow[t]{2}{*}{ Hausman } & 30.73 & & & 6.95 & 45.49 & \\
\hline & $(0.000)$ & & & $(0.434)$ & $(0.000)$ & \\
\hline M. Wald- & 8114.25 & & & & 4769.56 & \\
\hline heterosk & (0.000) & & & & $(0.000)$ & \\
\hline Baltagi-Wu LBI & 1.271 & & & 2.09 & 1.262 & \\
\hline $\begin{array}{l}\text { Bhargava Durbin- } \\
\text { Watson }\end{array}$ & 1.166 & & & 2.06 & 1.02 & \\
\hline \multirow[t]{2}{*}{ Pesaran CSD } & 8.936 & & & 6.968 & 4.692 & \\
\hline & $(0.000)$ & & & $(0.000)$ & $(0.000)$ & \\
\hline \multirow[t]{2}{*}{ Breusch Pagan LM } & & & & 0.000 & & \\
\hline & & & & (0.482) & & \\
\hline LM test for & & & & 0.84 & & \\
\hline autocorrelation & & & & (0.657) & & \\
\hline
\end{tabular}


Banking Regulation and Determinants of Banks' Profits: Empirical Evidence from Turkey

Table A.2. Determinants of bank profitability over 1995-2000 pre-BRSA

\begin{tabular}{|c|c|c|c|c|c|c|}
\hline & Fixed & Random & Fixed & Random & Fixed & Random \\
\hline & ROA & ROA & ROE & ROE & EPP & EPP \\
\hline \multirow[t]{2}{*}{$\mathrm{EA}$} & $0.141^{* * *}$ & $0.187^{* * *}$ & 0.243 & 0.178 & 0.015 & 0.018 \\
\hline & $(-0.038)$ & $(-0.034)$ & $(-0.406)$ & $(-0.297)$ & $(-0.016)$ & $(-0.011)$ \\
\hline \multirow[t]{2}{*}{ NLA } & -0.003 & -0.026 & 0.046 & $-0.731^{* *}$ & -0.011 & -0.016 \\
\hline & $(-0.029)$ & $(-0.029)$ & $(-0.317)$ & $(-0.285)$ & $(-0.011)$ & $(-0.009)$ \\
\hline \multirow[t]{2}{*}{ SIZE } & $0.745^{*}$ & $0.760 * *$ & 4.69 & $5.598 * *$ & $0.699 * * *$ & $0.370 * * *$ \\
\hline & $(-0.418)$ & $(-0.309)$ & $(-4.465)$ & $(-2.43)$ & $(-0.148)$ & $(-0.099)$ \\
\hline \multirow[t]{2}{*}{ CONC } & $-0.935^{* * *}$ & $-0.859 * * *$ & $-6.072 * * *$ & $-4.684 * * *$ & 0.024 & $0.102 * * *$ \\
\hline & $(-0.108)$ & $(-0.098)$ & $(-1.157)$ & $(-0.944)$ & $(-0.038)$ & $(-0.033)$ \\
\hline \multirow[t]{2}{*}{ OBS } & $-4.474 * *$ & -2.056 & -16.18 & $44.53 * * *$ & -0.459 & -0.514 \\
\hline & $(-2.17)$ & $(-1.908)$ & $(-23.17)$ & $(-17.19)$ & $(-0.77)$ & $(-0.637)$ \\
\hline \multirow[t]{2}{*}{ LIQ } & $0.071 * *$ & $0.091 * * *$ & -0.028 & $0.709 * *$ & -0.005 & 0.005 \\
\hline & $(-0.032)$ & $(-0.031)$ & $(-0.339)$ & $(-0.299)$ & $(-0.011)$ & $(-0.011)$ \\
\hline \multirow[t]{2}{*}{ CTS } & 0.049 & 0.042 & 0.049 & 0.214 & -0.007 & -0.005 \\
\hline & $(-0.039)$ & $(-0.036)$ & $(-0.424)$ & $(-0.337)$ & $(-0.014)$ & $(-0.012)$ \\
\hline \multirow[t]{2}{*}{ Constant } & $39.83 * * *$ & $32.56 * * *$ & $322.2 * * *$ & $161.1^{* *}$ & $-5.164^{*}$ & $-3.949 *$ \\
\hline & $(-7.735)$ & $(-6.927)$ & $(-82.59)$ & $(-64.95)$ & $(-2.743)$ & $(-2.332)$ \\
\hline R-squared & 0.418 & 0.398 & 0.189 & 0.113 & 0.3 & 0.266 \\
\hline \multirow[t]{2}{*}{ F stat } & 17.76 & & 5.74 & & 10.57 & \\
\hline & $(0.000)$ & & $(0.000)$ & & $(0.000)$ & \\
\hline \multirow{2}{*}{ Wald } & & 117.79 & & 52.74 & & 66.18 \\
\hline & & $(0.000)$ & & $(0.000)$ & & (0.000) \\
\hline Observations & 216 & 216 & 216 & 216 & 216 & 216 \\
\hline Number of id & 36 & 36 & 36 & 36 & 36 & 36 \\
\hline \multirow[t]{2}{*}{ Hausman } & & & 42.06 & & 26.65 & \\
\hline & & & $(0.000)$ & & $(0.000)$ & \\
\hline M. Wald- & 24464.11 & & 3904.24 & & 70672.26 & \\
\hline heterosk & $(0.000)$ & & $(0.000)$ & & $(0.000)$ & \\
\hline Baltagi-Wu LBI & 1.392 & & 1.944 & & 1.392 & \\
\hline $\begin{array}{l}\text { Bhargava } \\
\text { Durbin-Watson }\end{array}$ & 0.9703 & & 2.232 & & 0.97 & \\
\hline Pesaran CSD & 2.444 & & 2.575 & & 3.163 & \\
\hline & $(0.015)$ & & (0.010) & & $(0.002)$ & \\
\hline
\end{tabular}


Mahmut ERDOGAN \& E. Ebru AKSOY

Table A.3. Determinants of bank profitability over 2002-2007 post-BRSA

\begin{tabular}{|c|c|c|c|c|c|c|}
\hline & Fixed & Random & Fixed & Random & Fixed & Random \\
\hline & ROA & ROA & ROE & ROE & EPP & EPP \\
\hline \multirow[t]{2}{*}{$\mathrm{EA}$} & $0.161^{* * *}$ & $0.055^{* *}$ & $0.788 * * *$ & 0.13 & -0.012 & 0.003 \\
\hline & $(-0.043)$ & $(-0.025)$ & $(-0.177)$ & $(-0.099)$ & $(-0.009)$ & $(-0.007)$ \\
\hline \multirow[t]{2}{*}{ NLA } & $-0.350 * * *$ & $-0.379 * * *$ & $-0.503 * *$ & $-0.576 * * *$ & 0.004 & 0.003 \\
\hline & $(-0.052)$ & $(-0.041)$ & $(-0.211)$ & $(-0.167)$ & $(-0.010)$ & $(-0.009)$ \\
\hline \multirow[t]{2}{*}{ SIZE } & $1.798 * *$ & $0.628 * *$ & $9.633^{* * *}$ & $3.903 * * *$ & -0.164 & -0.033 \\
\hline & $(-0.801)$ & $(-0.274)$ & $(-3.276)$ & $(-1.098)$ & $(-0.161)$ & $(-0.079)$ \\
\hline \multirow[t]{2}{*}{ CONC } & -0.117 & -0.32 & -1.08 & -1.148 & $0.172 * * *$ & $0.153^{* * *}$ \\
\hline & $(-0.287)$ & $(-0.265)$ & $(-1.176)$ & $(-1.085)$ & $(-0.058)$ & $(-0.055)$ \\
\hline \multirow[t]{2}{*}{ OBS } & $-16.82 * * *$ & -1.174 & $-54.52 * * *$ & -6.618 & 0.863 & 0.537 \\
\hline & $(-4.083)$ & $(-2.125)$ & $(-16.71)$ & $(-8.55)$ & $(-0.82)$ & $(-0.558)$ \\
\hline \multirow[t]{2}{*}{ LIQ } & $0.064 *$ & $0.056 * *$ & 0.14 & 0.099 & $-0.018^{* *}$ & $-0.011^{*}$ \\
\hline & $(-0.036)$ & $(-0.027)$ & $(-0.149)$ & $(-0.109)$ & $(-0.007)$ & $(-0.007)$ \\
\hline \multirow[t]{2}{*}{ CTS } & 0.059 & $0.047^{*}$ & -0.028 & 0.034 & -0.008 & -0.009 \\
\hline & $(-0.042)$ & $(-0.028)$ & $(-0.17)$ & $(-0.111)$ & $(-0.008)$ & $(-0.007)$ \\
\hline \multirow[t]{2}{*}{ Constant } & -25.86 & 8.701 & -104.3 & 10.51 & 2.16 & 0.461 \\
\hline & $(-23.11)$ & $(-19.72)$ & $(-94.59)$ & $(-80.63)$ & $(-4.64)$ & $(-4.099)$ \\
\hline R-squared & 0.32 & 0.243 & 0.165 & 0.06 & 0.085 & 0.07 \\
\hline \multirow[t]{2}{*}{ F stat } & 11.65 & & 4.88 & & 2.3 & \\
\hline & $(0.000)$ & & $(0.000)$ & & ( 0.028) & \\
\hline \multirow[t]{2}{*}{ Wald } & & 104.46 & & 30.72 & & 12.25 \\
\hline & & $(0.000)$ & & $(0.000)$ & & ( 0.09$)$ \\
\hline Observations & 216 & 216 & 216 & 216 & 216 & 216 \\
\hline Number of id & 36 & 36 & 36 & 36 & 36 & 36 \\
\hline \multirow[t]{2}{*}{ Hausman } & 26.91 & & 24.72 & & & 8.93 \\
\hline & $(0.000)$ & & $(0.000)$ & & & $(0.257)$ \\
\hline \multirow[t]{2}{*}{ M. Wald- heterosk } & $1.50 \mathrm{E}+05$ & & 19307.23 & & & \\
\hline & $(0.000)$ & & $(0.000)$ & & & \\
\hline Baltagi-Wu LBI & 1.737 & & 2.109 & & & 2.214 \\
\hline $\begin{array}{l}\text { Bhargava Durbin- } \\
\text { Watson }\end{array}$ & 1.506 & & 1.822 & & & 1.812 \\
\hline \multirow[t]{2}{*}{ Pesaran CSD } & 0.639 & 0.065 & & & 2.799 & \\
\hline & (1.477) & (1.05) & & & $(0.00)$ & \\
\hline \multirow[t]{2}{*}{ Breusch Pagan LM } & & & & & & 71.74 \\
\hline & & & & & & $(0.00)$ \\
\hline LM test for & & & & & & 79.87 \\
\hline autocorrelation & & & & & & $(0.00)$ \\
\hline
\end{tabular}

